\title{
BARRIERS TO THE DIGITAL AND PHYSICAL ACCESSIBILITY OF THE RELIGIOUS CULTURAL HERITAGE OF "HOLY MOUNT" OF SOFIA
}

\author{
G. Bogdanova', L. Galabova ${ }^{2}$ \\ g.bogdanova@gmail.com; lianagalabova@abv.bg \\ 1 Institute of Mathematics and Informatics at the Bulgarian Academy \\ of Sciences, Sofia, Bulgaria \\ 2 Independent Researcher, Sofia, Bulgaria

\begin{abstract}
Accessibility of religious centres and their additional hierotopical natural and architectural spaces, although implied by virtues of responsibility, solidarity, care, charity, and love, does not seem to be internal characteristic priority in confessional specifics of socialisation of private and public places by Eastern Orthodox Christian Church. Management of living heritage (traditional and reconstructed), as well as of tangible (movable and immovable) church cultural heritage, of artworks and art performances according to their artistic value, and of feasts and practices, according to their touristic potential is accomplished mostly in the interest of their liturgical confessional function in the context of Eastern Orthodox Christian subcultural lifestyle in its whole traditional and contemporary global variety.
\end{abstract} \\ Keywords: Cultural Heritage; Sacred Sites; Accessibility; \\ Special Needs; Tourist Socialisation; Subcultures; Monuments of \\ Culture; Eastern Christian Orthodox Church; Pilgrimage tourism; \\ Holly Mount of Sofia
}

\section{БАРИЕРИ ПРЕА АИГИТААНАТА И ФИЗИЧЕСКАТА АОСТЪПНОСТ НА РЕАИГИОЗНОТО КУАТУРНО НАСАЕАСТВО НА СОФИЙСКАТА СВЕТА ГОРА}

Г. БОГАанова ', А. ГъАъбова ${ }^{2}$

1 Институт по математика и инорорматика при Бьлгарска акалемия на науките, Софрия, България

2 Изследовател на своболна практика, Софии, България

Резюме: Аостьпността на религиозните центрове и прилежащите им йеротопични природни и архитектурни пространства, макар и заложена с мобродетелите на 
отговорността, съпричастието, грижата, милосърАието и ^юбовта в православната цьрква изглежла не е вътрешноприсъщ приоритет на вероизповедните особености на социализация на частни и обществени места. Управлението на живото, традиционно и възстановено, както и на материалното, Авижимо и неАвижимо църковно културно наслеАство, на произведенията и проявите на изкуствата спореА художествената им стойности и на празниците и обичаите спореА туристическите им измерения, се осъществява предимно в интерес на Аитургичното им вероизповеАно предназначение в контекста на православния субкултурен начин на живот в цялото му тралиционно и Съвременно гАокално разнообразие.

КАючови Ауми: Културно наследство; Свети места; Аостъпност; Специални потребности; Туристическа социализация; Субкултури; Паметници на културата; Православна църква; Поклоннически туризъм; Софрийска света гора

Софрийското светогорие е съвременен туристически конструкт организиран около обществените мероприятия по социализацията на религиозните обекти на Българската православна църква известни от миналото като Мала света гора, каквито принципно съществуват като потенциал или реализация при всяко селище. Обичаят възникнал от желанието $\Delta$ а се обособят свещени пространства (Douleva, 2019), от различни по големина храмове и манастири Ао проскинитарии, кръстове или иконостаси (и във виА на макети на цьркви), на обществени места в храмове, параклиси, гробищни и селищни паркове, офиси, хотели, дворове и домове, среА природата (планински, крайпьтни, при водни басейни, пещери, мини, на полярни и поАвоАни места) цеАи почитането на възможно повече светии с кътчета, къАето $\Delta а$ им се отАава почит в Аеня на общоцьрковното им честване. Разгръщането на този йеротопичен принцип на изпросване на невиАимото небесно застьпничество на все повече места, сьпроволено с утвърждаване на паството, духовна защита на селището и укрепване на вярата на хората е вътрешно присъщ механизьм на православната 
цьрковна общност, наличен и в практиките на Аругите инославни и иноверни вероизповедания (Bakalova, 2016).

Стремежьт да се постигне оптимална гражданска и туристическа Аостъпност еАновременно с поклонническата и богослужебната, към която приналлежат и храмовите празници и цьрковните обичаи, иАва от миналото, когато в съответствие с историческите времена е имало сътрудничество на светската и Ауховната власти и традиционните общности и общества воАени от тях. Възниквали са Аори обители, чиято мисия е била грижа за поклонниците, Аокато съвременните тенденции са противоположни.

Колкото и постмодерните условия $А$ а не кореспондират със стриктното възстановяване на изгубената в промените система от религиозни центрове, без реално да има проспериращи селищни общности, които Аа ги осмислят, толкова и за обществото и Аържавата, но особено за профресионалистите в областта на селищното устройство и управление и културното наслеАство е неоправ $А$ ано $\Delta$ व се търпи и насьрчава обезлюдяването и разрухата. Културната значимост на някои обекти на цьрковните изкуства понякога съвсем (и право и обратно пропорционално) не кореспондира с богослужебното предназначение на светите места, които би слеАвало $А$ с са съзАалени за уединение срел природата или селищната архитектура среда, в усамотение и тишина и само на празник $а$ а се изпьлват с народ, суетня и веселба. Анес условията поставят храма преАизвикателно за благочестивото въображение: в мол, в политически клуб, насреА пазара на п^ощала, срел бурените в гората, на скалата, на врьх п^анината, в Аерето, в пещерата, на морското Аьно, на п^ажа, пол язовир или пьт, в по $\wedge$ еза, метрото, музея, в товарния превоз или склала, в компютьра или смартфона и изобщо във виртуалното пространство, точно както и Бог е навсякьАе и невиАимата цьрква е винаги заеАно с виАимата или поне много близко.

Твърде светските стремежи на хората са породили лов на чудеса, покоряване на свети места, завоюване на свещени пространства, запечатване на чулесни събития и почти медиен интерес 
към цьрковното ежелневие, украса, багаж в залния Авор, проблеми, ск^аА, стопанство, храмови строеж или ремонт и руини.

От глеАна точка на Анешната социализация на цьрковните пространства, едва ^и има по-обезкуражаваща за вероизповеданието реалност от разрушените цьркви из красивите кътчета на цялата страна. Изоставени са къщи, махали и цели села и краища порали белността, миграцията и демографрската криза и е трудно $а$ се мисли, че те са само временно опустели, не са се превьрнали в мемориал и евентуалното им възстановяване няма $ы$ а е бутадрорно, порали което е по-лобре $\Delta а$ се пренесат в музейни пространства. В миналото съборите осъществят връзката межлу представителите на тези общности, Анес за това сьлействат и медии, проекти, архиви, АИгитаАни колекциИ...

Краезнанието и инорраструктурните проекти Анес не са Аостатьчни $А$ в възърнат живота в селските райони, както някога системата за опазване на културното наследство е успявала $\Delta а$ „върне живота назал". Анес туристификацията, която е по-вероятен механизъм на опазване, не може да разчита на полкрепата на такива централизирани, монополизирани, субсидирани и планирани системни Аейности, но Аостьпностите гарантират устойчивостта. Подсигуряването на минималната степен на Аостьпност (Bogdanova, 2017) на религиозните обекти за хората със затруднения, уврежАания и неравностойно положение е енно Аобро начало.

Нужни са разяснения за персонала и посетителите, указателни табели и известно старание, докато стане ясно, че има категории хора, които не могат $\Delta$ а стигат $\Delta$ о светите места и $\Delta$ а остават там, ако не са спазени основни хигиенни изисквания (освен рампите) като санитарен възе^ и вентилация. В Аетайли, отоп^ението в зимните месеци, защитата

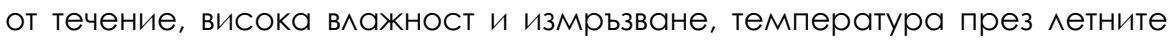
месеци $\Delta о \quad 23^{\circ}$ и засенчването са зальлжителни условия за функционирането на обществени сгради. Комплексната сетивна

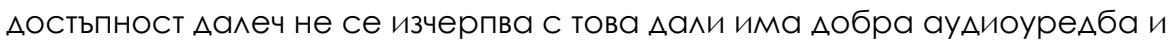
видимост. Безкрайни са Аискусиите за богослужебния език, Аикцията и когато богослужението се води на български. 
Но малко се оценява това, че често за част от хората в храма

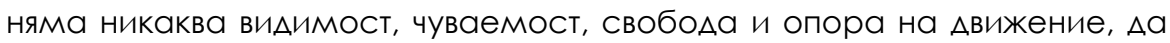
не говорим, че когато са притеснени поради фоизически или психичен проблем, който може $а$ а се реши с благоустрояване, значителна група от хората не успяват $а$ а се съсредоточат и $а$ с съпреживеят събитията или Аа комуникират и Аа се социализират нормално.

Причината за празните храмове, освен ако все още някьАе не предпочитат $А$ не илва никой, както в социалистически тип бюАжетна институция, не е и само в мипсата на срелства за цьрковнослужители. Аезориентацията на незрящите и слабо чуващи вярващи при запалени свещи, бльсканица и мипса на мица, които Аа регулират човекопотока пренасочва масата от вярващи към извьнбогослужебното време, когато в храмовете е спокойно и тихо. Това ограничава общностността на хората, които не участват в неАелни ^итургии, в бАения срещу големи празници, неделно училище и във времето за социализация слеА

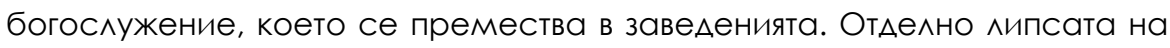
Аетски кът и място за хранене, както и на дейности за млалежи и възрастни хора издава нежелание за масово привличане на белни енориаши, а за предпочитание към дарители.

Инорормационна и Аокументална Аостьпност установена чрез анализ на особеностите на наличната изобилна туристическа инорормация за религиозни обекти, показва слеАните проблеми:

- ЕАнотипност, обобщеност и абстрактност на инорраструктурната и културна оценка

- Невъзможност да се степенува състоянието на свещените обекти

- Фрагментарно преАставят цьрковната визия, мисия и ценности

- Не съчетават туристически и поклоннически интереси

- Не гарантират оптимален Аостьп Ао обектите

- Не са систематизирани всички налични обекти

- ИзАанията популяризиращи светогорието и отАелните обекти не са

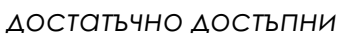

- В повечето случаи няма Аостьпени добре профоилиран културен календар 
Организацията на комплекса „Софрийска света гора" все още не е насочена кьм хора сьс специални потребности или ниськ социален статус, а извьн стандартните екскурзии, за повечето обекти предполага мичен транспорт или пешехолни прехоли, но в същото време повечето нямат и нефрормални посетителски центрове и добра туристическа индрраструктура. Разработката и социализацията на неАвижимото И Авижимо материално културно наслеАство, въз основа на живото или нематериално богатство на православната култура е профресионална отговорност на множество експерти, някои от които съчетават архитектурното и реставраторско, геоградрско и туристическо, спортно, пеАагогическо, икономическо и Аруго гражАанско призвание с богословската и АУховна поАготовка, вслеАствие на което на проектно ниво благоустройството е полсигурено.

Пок^онническо-туристическа структура "местно светогорие“ (Piperkov, 2015) се организира и представя, според резултатите от настоящото проучване, по спираловиден, ралиален, цикличен и мрежов модели. При пьрвия случай поклонничеството е като художествен наратив, който трьгва от най-близкия храм и постепенно обхваща по-Аалечни обекти като по Пътя си вКАЮчва нови И нови места С тяхната също така

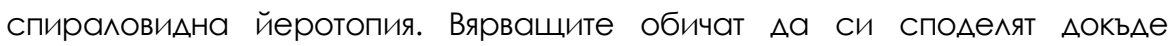
Аостигат техните впечатления в определени етапи от живота им и обменят впечатления и познания, обсъжАат къАе обикновено ХоАят на Аален празник всяка ГоАина и КъАе п^анират Аа отиАат по-Аалеч От познатия им Свещен периметър. РаАиалният молел е свързан с това какъв е инАивиАуалният, групов или Масов Аостьп АО свети места и понякога се изразява в струпването на вярващи от кварталите в еАин граА или от съсеАните села, на мястото, където е храмов или Аруг църковен празник, сбор, курбан,

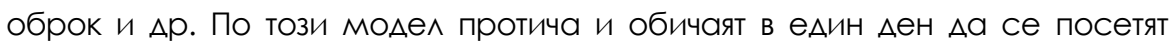
няколко църкви за зАраве или при житейски проблем, както и някои ИНАИВИАУААНИ ПОКАОНнИчеСКИ МарШРУТИ АО ИкОНИ И^И МОЩИ, коИтО се практикуват, например по пьтя Кьм работно място, роднини, търговски центьр, транспортен възел и Аруги.

Във всяко селище има такива поклонничекски ^ьчи, очертани от самата инфраструктура като реки, улици, граАинки, по обичайния хоА 
на разхолките и Аруги елементи на обществения живот на $А$ Аено място. За Софрийското светогорие това са миниите на метро, трамваи, автобуси, тролеи, маршрутни таксита спрямо гари, булеварди, паркинги и Аруги инорраструктурни дадености, но и съществуващите вече поклоннически маршрути в процес на трасиране.

ЦикАичният моАеА, както спираловиАният и раАиалният съответства на пътническия опит и разбирането на съображенията за Аична и обществена безопасност в Аалено селище и среА природата, но най-улобен от глеАна точка на риска е мрежовият. Крьговете преАполагат опити $\Delta а$ се посещават равностойни по отАалеченост и разположение свещени обекти, а градоустройствените планове и тяхната реализация слелва $А$ о отразяват в алекватна туристическа инорормация ранга на обектите по редица показатели към момента на пьтуването. Аостьпността, без това понятие Аа означава непрекъснат феестивал или постоянни Ани на отворените врати, изисква кратки, точни и ясни указания за актуалното състояние на религиозните обекти, но много по-подробно обяснени от това, което може $а$ а се намери като тиражирани отзиви и препорьки. Преките впечатления от пътепис и фотографиите и сегашните определения: Аействащ, неАействащ паметник на културата от местно и национално значение са съвсем условни и поАробните репортажи на руските покАонници Аават много по-ясна представа за това какво може да се очаква и желае на място. Коректността към хората с уврежАания, социално неравностойни и със затруднения (Таблица №2), колкото и те у нас да не се оценяват като значителен туристически контингент, предполага идеята за пьтуване Ао определено свето място $\Delta а$ е представена и през техните преживявания.

Именно мрежовият потребителски или комбиниран пок^оннически модеА на организация на посещенията на свети места позволява, с риск от обвинения в капризност или асоциалност, Аа се полберат само местата с плавен Аостьп кьм входовете, наличие на вода, сянка, пейка, за̀вет и санитарен възел, място за хранене, игра, паркиране, багаж иживотни. 
Туристифоцираните и музеифицирани свети места, при цялата си социализация на еАно приветливо място, от което на хората не им се тръгва обратно, изискват и гостоприемно Ауховно присъствие, както и манастирите с усьрден Ауховен живот имат посетителски центрове и хотели, тъй като Ауховните пространства не са асоциални при жива традиция и приемственост. Когато в еАно селище, както е описана Бистрица в миналото или Охрил понастоящем, а и както са били организирани повечето еАновремешни общности и места, има оброци за всички празници, хората живо почитат светии и свещени събития, като се събират там, изграждат параклиси и храмове, когато е благословено.

При миграциите за външните наблюдатели не става ясно точно как и защо се създават и подАьржат свети места в обезлюАени И запустели селища и направо сред природата, в планината, освен от обяснението, че родовете си носят славите със себе си, в сърцето си... По-нататьк иАва въпросът Аали манастири, цьркви, параклиси, оброци, аязма се строят на най-хубавите, най-високите или на най-пустите и неАостьпни места или на най-равните и обширни. Аали всяко свето място е различно спореА хората и се мени с тях през годините или има някакви основни виАове, среА които еАните трябва $А$ с са Аостьпни, а Аругите $а$ а не са, или поне Аа имат Аостьпна и неАостьпна части. Това е добра тема за размисьл по пьтя за Кокалянския и еАин от Бистришките манастири, кълето поради Аенивелацията на терена спира Аъхът.

И в мирно време манастирите са създавани далеч от света, извън центьра или крепостта и Аалеч от пьтя. В размирно време светите места също имат защитни сьорьжения и персонал, при преселванията се изоставят, заключени, засипани или не и приналлежностите им се взимат. При Аруги обстоятелства, метосите на манастири и женските обители се е налагало $А$ б бьлат в центьра на селищата, Аа пазят ценности, Аа развиват милосьрАна и стопанска Аейност, ако не и $а$ а имат пансиони и семинарии. Енорийските храмове са строени не случайно в центьра на селището или махалите, като целта е била Аеца и възрастни $\Delta а$ могат $\Delta а$ Аостигат $\Delta о$ тях по най-бързия и лесен начин от

BARRIERS TO THE DIGITAL AND PHYSICAL ACCESSIBILITY OF THE 
Аомовете си. При празници, обичаи, отлелни събития камбаната е събирала всички.

Изключение са били Аомашните параклиси и Аворцови храмове, книжовните центрове, лаврите или Аруги монашески структури, общежитийни или иАиоритмични, отАалечените стопанства, пещери, острови, колиби, килии, подворията при посолствата и залграничните мисии, цьрковната Аиаспора, представителствата - метоси и конаци, прицьрковните организации на XX век и религиозните места оцелели през социализма и постсоциализма. Констуирането на Сооийското светогорие като носители на културно-историческо наслелство (Georgieva-Angelova, 2013) Аатира назал в миналото, когато процьфтяват ^аврите с книжовни центрове. Националният мит и Аьржава свързват историческата памет с военновременната идея, че руините са средоточие на ценен спомен, който може $л а$ се възкреси и така се съзаява храмостроителната инициатива на прицьрковното езотерично Авижение „Аобрия самарянин" С патриотичните популярни женски кампании на Бона Велинова, които са увековечени от Аесетки възАигнати през XX век сгради и облагородени и социализирани свети места в Софийско и из страната (Valchinova, 2006).

Без това гражАанско Авижение, което тогава битува в православните среди въз основа на развитието на модерни субкултурни практики и Аава реАица изявени цьрковници и АО Анес,

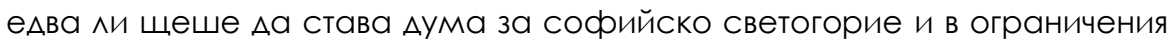
му обхват от 14 крайградски манастира, някои от които възстановявани невеАнъж в по-ново време. Все още не са проучени напьлно историите на тези места и може $а$ а се каже, че в цьрковния живот някой от тях са предимно „за украшение", а други все още не изглежлат достатьчно Аобре, въпреки, че са много посещавани. Постигането на формално регламентираната туристическа приголност, колкото и Аа изглежАа като намеса и в ущьрб на религиозните общности и обитаваните от тях места, съществено подпомага проявата на гостоприемство и грижа за сигурността на местните енориаши или монашестващи, на пок^онници и меАии. Като съзнава това пьрвоначално преАназначение на обгрижването на поклонници съчетано с Аобруването на местните 
жители и просперитета на селищата и страната, Ауховенството Аобре оценява туристическия фрактор за издръжката на религиозните центрове И консолиАирането на техния състав чрез изявата на илентичности.

Вниманието към състоянието на Аостьпността на религиозните обекти у нас, предмет на предишна разработка в настоящата електронна научна поредица, във връзка с храмовете в столичния центьр или стар грал (Shabarkova-Petrova and Galabova, 2018), предполага продьлжение на плодотворния анализ на елементи от

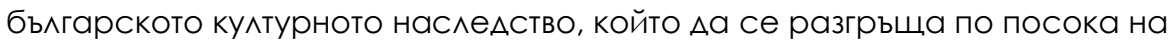
столичната община и област, регионите на страната и Балканите и $А а$ Аостигне Ао глобалните перспективи, всички от които Анес са Аобре проучени и регламентирани. Паралелно с благоговейното отношение към светите места, съпричастността по проблемите на културното наследство и уважението към хората и обичаите обживяващи сравняваните от нас обекти, потьрсихме възможности за Аетайлизиране на практическите аспекти на Аостьпността на среАата, приветливостта на климата и гостоприемството на представители и посетители на разнообразните по Ааленост български сакрални пространства. Аостъпността в целия спектър на мисията на вероизповедните общности на служение, вк^ючваща обслужване на ближните и като клиенти на туристическите Аейности е важна за социализацията на религиозните обекти - Аигитална (Sabev and Bogdanova, 2018), Аокументална, богослужебна, поклонническа, педагогическа, инорормационна и Аруги (Таблици 1, 2 и 3).

Туристическият поАхоА от сорерата на услугите е улеснение в преололяването на тенденциите на клерикализъм и изолационизьм в православието. Затова не разглежламе установяването и полобряването на разнообразните Аостьпности само като препорьчителни мерки, а като волещи принципи, на които $\Delta а$ се изгради онази част от мисията на религиозните общности, външна и вътрешна, която Аа повиши имиАжа на коноресионалните институции и организации и вярващи мица, Аа оптимизира значително управлението им и така $\Delta а$ привлече със социалната си отговорност и мобилност полкрепата на Аьржавата и обществото.

BARRIERS TO THE DIGITAL AND PHYSICAL ACCESSIBILITY OF THE RELIGIOUS CULTURAL HERITAGE OF THE "HOLY MOUNT" OF SOFIA CITY 
Проведените от нас пилотни проучвания на Аостьпността като фактор за туристическа социализация в отлелни обекти по време на празнични и ежеАневни цьрковни събития, както и на съответствието на меАийната и реалната поклонническа и митургична инорормация се изразяват в обобщението на слеАните основни критерии за оценка и разработване на обществен тип религиозен обект ${ }^{1}$ :

- Уебсайт, блог, профрил, страница и група в социални мрежи, мобилна връзка, Аиректно излъчване, визитка, брошура, сувенири, брандирана селскостопанска, издателска и занаятчийска продукция, инорормационни табла, приемна, представителни мица, магазин...

- Справка в общинска платорорма и регистри на храмовете, фотогалерия, репортажи в медиите, видеоматериали, проучвания...

- Историческо изследване, архивирана, Аигитализирана и Аостъпна онлайн Аокументация, експертна оценка на културноисторическото наследство, участие в проекти и програми за поААръжка и развитие, събития в общинския културен каленАар...

- УтвърАени образователни и социални инициативи и пространства, школи по изкуства, стопанска, проектна и ремонтна Аейност, сътрудничества, културен каленАар, посетителски център, екскурзовоА, планински воАач, разписание на богослужението...

- Хуложествено офрормление на архитектурата, манАшафрта и интериора, творчески проекти, сакрално и туристическо брандиране, визуална комуникация, техническо полсигуряване...

- Сведения за възможностите за отлих и забавление, паркиране и настаняване, хранене и обгрижване на различни възрастови групи и за Аостьпността за Аеца, възрастни, хора с уврежАания, наличие на меАицински центьр, гралски, селски, междуселски, межлуградски, межлународен транспорт, връзка с болница,

\footnotetext{
' Някои храмове и манастири са организирани като частни (жилищни или вилни)
} обекти с ограничен Аостьп спореА потребностите на общността 
полиция, пътна помощ, метище, туроператори, връзка с Аруги обители, енории, институции и организации...

Особеностите на йеротопичните решения на „Софрийското светогорие", по-конкретно, атмосорерата и фризическия Аостьп $А$ о популярните цьрковни обекти в Софийско може да се наблюАава чрез проучването на съвременните градоустройствени процеси. Като се отграничава разглежлането на частите от Софийската Мала света гора намиращи се в Софрия-област с прилежащите иे Ауховни околии и техните възраждащи се светогория, тук поставяме акцент на свещените обекти в Софрия-грал, в продьлжение на изучаването на случващото се в центьра и преАимно в стария граА в посока на няколко нива Квартали и агломерации към перифрерните свети места. От Ауховна гАеАна точка и с оглеА на изтласкването на Ауховния живот в отАалечени части на селищата за да се маргинализира, елновремешните перифрерни свети места Анес отговарят Аобре на разрастването на Софиия като вече УтвьрАени среАоточия на традиции.

От центьра на града, през старите столични квартални храмове към Аинамичните агломерации и жилищни комплекси на XX век и софийските села се Аостига Ао сьсенните светогория, които още в миналото са различни по своите обичаи и население. Най-общо може $\Delta a$ се каже, че цьрквите изгралени в старите централни и по-Аалечни квартали и агломерации имат по-Аобра Аостьпност от централните и онези, които са в предп^анинските и п^анински местности. АонякъАе това се Аьлжи на по-скромната архитектура, а ползването прелимно на мичен транспорт от населението в тези части на града и опитьт в пешеходния туризьм гарантират по-добрата оризическа и географрска $\triangle О С т ь п н о С т$. 


\section{Таблица 1. ВиАове социализация на църковните обекти}

\begin{tabular}{|c|c|c|c|}
\hline $\begin{array}{c}\text { ВИАОВЕ } \\
\triangle O C T Ъ П H О С Т\end{array}$ & ОПТИМААНА & CPEAHA & МИНИМАへНА \\
\hline Аигитална & $\begin{array}{l}\text { Уебсайт, блог, } \\
\text { профрил, } \\
\text { страница или } \\
\text { група в } \\
\text { социалните } \\
\text { мрежи, } \\
\text { смислени } \\
\text { репортажи с } \\
\text { информация и } \\
\text { оценки }\end{array}$ & $\begin{array}{l}\text { Брошура, } \\
\text { книга с } \\
\text { историята на } \\
\text { храм, } \\
\text { обител, } \\
\text { селище, } \\
\text { Ауховенство, } \\
\text { патрон, } \\
\text { дарители }\end{array}$ & $\begin{array}{l}\text { Инорормация на } \\
\text { общински } \\
\text { уебсайт, в } \\
\text { местни архиви, } \\
\text { библиотеки, } \\
\text { преса, } \\
\text { краеведски } \\
\text { издания,проекти, } \\
\text { програми, } \\
\text { конкурси }\end{array}$ \\
\hline ИзслеАователска & $\begin{array}{l}\text { Историческо } \\
\text { проучване }\end{array}$ & $\begin{array}{l}\text { Статия и } \\
\text { картички }\end{array}$ & $\begin{array}{l}\text { Брошура и } \\
\text { визитка }\end{array}$ \\
\hline Пок^онническа & $\begin{array}{l}\text { Почивни Ани, } \\
\text { големи } \\
\text { християнски } \\
\text { празници, } \\
\text { тайнства и } \\
\text { треби, } \\
\text { душегрижие } \\
\text { при } \\
\text { необходимост }\end{array}$ & $\begin{array}{l}\text { Големи } \\
\text { цьрковни } \\
\text { празници, } \\
\text { именни Ани, } \\
\text { тайнства и } \\
\text { треби }\end{array}$ & $\begin{array}{l}\text { Събор веАнъж } \\
\text { или няколко пьти } \\
\text { годишно, Книга } \\
\text { за посетитеАи и } \\
\text { пок^онници }\end{array}$ \\
\hline Богослужебна & Ежедневен крыг & $\begin{array}{l}\text { Седмичен } \\
\text { крьг }\end{array}$ & Годишен крьг \\
\hline
\end{tabular}

Таблица 2. Въпросник за оценка на приспособеност на църковните обекти

\begin{tabular}{|c|c|c|c|c|c|}
\hline $\begin{array}{l}\text { КАТЕГОРИИ } \\
\text { НАСЕАЕНИЕ }\end{array}$ & $\begin{array}{l}\text { ЕНОРИАШ } \\
\text { ГОСТ } \\
\text { САУЖИТЕА } \\
\text { КАИР }\end{array}$ & $\begin{array}{l}\text { ПОАГОТВЕНИ } \\
\text { ЕНОРИАШИ }\end{array}$ & $\begin{array}{l}\text { ПОАГОТВЕН } \\
\text { ПЕРСОНАА }\end{array}$ & $\begin{array}{l}\text { ПРОМЕНЕН } \\
\text { ИНТЕРИОР }\end{array}$ & $\begin{array}{l}\text { ПРОМЕНЕН } \\
\text { ЕКСТЕРИОР }\end{array}$ \\
\hline $\begin{array}{l}\text { Спешни } \\
\text { сьстояния }\end{array}$ & & & & & \\
\hline Заболявания & & & & & \\
\hline $\begin{array}{l}\text { СьрАечно- } \\
\text { сьАОви }\end{array}$ & & & & & \\
\hline Вестибуларни & & & & & \\
\hline Инорекциозни & & & & & \\
\hline ЕнАОкринни & & & & & \\
\hline ОнкОАОГИчнИ & & & & & \\
\hline $\begin{array}{l}\text { Нервно- } \\
\text { психични }\end{array}$ & & & & & \\
\hline
\end{tabular}




\begin{tabular}{|c|c|c|c|c|c|}
\hline $\begin{array}{l}\text { КАТЕГОРИИ } \\
\text { НАСЕАЕНИЕ }\end{array}$ & $\begin{array}{l}\text { ЕНОРИАШ } \\
\text { ГОСТ } \\
\text { САУЖИТЕА } \\
\text { КАИР }\end{array}$ & $\begin{array}{l}\text { ПОАГОТВЕНИ } \\
\text { ЕНОРИАШИ }\end{array}$ & $\begin{array}{l}\text { ПОАГОТВЕН } \\
\text { ПЕРСОНАА }\end{array}$ & $\begin{array}{l}\text { ПРОМЕНЕН } \\
\text { ИНТЕРИОР }\end{array}$ & $\begin{array}{l}\text { ПРОМЕНЕН } \\
\text { ЕКСТЕРИОР }\end{array}$ \\
\hline \multicolumn{6}{|l|}{$\begin{array}{l}\text { Опорно- } \\
\text { Авигателни }\end{array}$} \\
\hline \multicolumn{6}{|l|}{ Костно-ставни } \\
\hline \multicolumn{6}{|l|}{ Респираторни } \\
\hline \multicolumn{6}{|l|}{ Алергични } \\
\hline \multicolumn{6}{|l|}{ Стомашни } \\
\hline \multicolumn{6}{|l|}{ Бъбречни } \\
\hline \multicolumn{6}{|l|}{ Кожни и ХИВ } \\
\hline \multicolumn{6}{|l|}{ Стоматологични } \\
\hline \multicolumn{6}{|l|}{ Специорични } \\
\hline \multicolumn{6}{|l|}{$\begin{array}{l}\text { УврежАания и } \\
\text { затруднения }\end{array}$} \\
\hline \multicolumn{6}{|l|}{$\begin{array}{l}\text { Слухово- } \\
\text { речеви }\end{array}$} \\
\hline \multicolumn{6}{|l|}{ Зрителни } \\
\hline \multicolumn{6}{|l|}{$\begin{array}{l}\text { Опорно- } \\
\text { Авигателни }\end{array}$} \\
\hline \multicolumn{6}{|l|}{ Психични } \\
\hline \multicolumn{6}{|l|}{$\begin{array}{l}\text { НапреАна^а } \\
\text { възраст }\end{array}$} \\
\hline \multicolumn{6}{|l|}{ Ранно Аетство } \\
\hline \multicolumn{6}{|l|}{ Неучащи деца } \\
\hline \multicolumn{6}{|l|}{ Многодетни } \\
\hline \multicolumn{6}{|l|}{ Мигранти } \\
\hline \multicolumn{6}{|l|}{ Безработни } \\
\hline \multicolumn{6}{|l|}{$\begin{array}{l}\text { Неравностойно } \\
\text { положение }\end{array}$} \\
\hline \multicolumn{6}{|l|}{$\begin{array}{l}\text { Социално } \\
\text { слаби }\end{array}$} \\
\hline \multicolumn{6}{|l|}{$\begin{array}{l}\text { Социална } \\
\text { изолация }\end{array}$} \\
\hline \multicolumn{6}{|l|}{ БезАомни } \\
\hline \multicolumn{6}{|l|}{ Самотни } \\
\hline \multicolumn{6}{|l|}{ ОбезАвижване } \\
\hline \multicolumn{6}{|l|}{$\begin{array}{l}\text { Замьрсени } \\
\text { райони }\end{array}$} \\
\hline \multicolumn{6}{|l|}{$\begin{array}{l}\text { ОтАалечени } \\
\text { райони }\end{array}$} \\
\hline $\begin{array}{l}\text { СпореА } \\
\text { заетостта }\end{array}$ & & & & & \\
\hline
\end{tabular}

BARRIERS TO THE DIGITAL AND PHYSICAL ACCESSIBILITY OF THE RELIGIOUS CULTURAL HERITAGE OF THE "HOLY MOUNT" OF SOFIA CITY

GALINA BOGDANOVA, Assoc. Prof., PhD, g.bogdanova@gmail.com,

LIANA GALABOVA, PhD student, lianagalabova@abv.bg 
Таблица 3. Критерии и показатели на Аостьпностите на религиозен обект

\begin{tabular}{|c|c|}
\hline $\begin{array}{c}\text { ВИА } \\
\triangle \text { ОСТЬПНОСТ }\end{array}$ & КРИТЕРИИ ЗА ОЦЕНКА И ПОАСИГУРЯВАНЕ \\
\hline Аитургична & $\begin{array}{l}\text { Налице ^и са условия за богослужение; какво и } \\
\text { как може да се отслужи, целева група }\end{array}$ \\
\hline Аушепастирска & $\begin{array}{l}\text { Внимание и гостоприемство към всички и } \\
\text { вьзможност да се черкуват там }\end{array}$ \\
\hline Информационна & 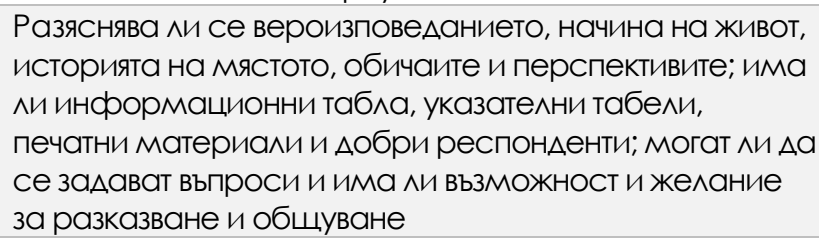 \\
\hline Виртуална & $\begin{array}{l}\text { Има ^и глобален Аостьп, мелия, изльчване, } \\
\text { дигитализация, вилеостена, GPS, постоянно } \\
\text { вилеонаблюление, запис, охрана, врьзка с } \\
\text { полиция, комуникации }\end{array}$ \\
\hline $\begin{array}{l}\text { Йеротопична и } \\
\text { възпоменателна }\end{array}$ & $\begin{array}{l}\text { Има ^и специфрична атмосорера в Аелник и } \\
\text { празник, Аостьпен ли е вьтрешният живот, } \\
\text { подАьржа Аи се живо инАивиАуално и колективно } \\
\text { цьрковно сьзнание }\end{array}$ \\
\hline $\begin{array}{l}\text { МеАийна и } \\
\text { фестивална }\end{array}$ & $\begin{array}{l}\text { Аостьп за свои и външни мелии, представителен } \\
\text { или реален; има ли желание за присьствие в } \\
\text { медиите и Ао каква степен, рек^амно или реално }\end{array}$ \\
\hline Правозащитна & $\begin{array}{l}\text { Рискове и превенция на Аискриминация, в } \\
\text { указателните и информационни табла, табели, } \\
\text { поведение на клисари към туристи, посетители } \\
\text { към Ауховенство, отношение към/на Аеца, } \\
\text { младежи и вьзрастни }\end{array}$ \\
\hline $\begin{array}{l}\text { Научно- } \\
\text { изслелователска }\end{array}$ & $\begin{array}{l}\text { Статистика, архив, Аостьп, защитени лични Аанни и } \\
\text { специфични наблюАения, опазване на наслеАството, } \\
\text { Аокументация, проучвания, публикации }\end{array}$ \\
\hline Техническа & $\begin{array}{l}\text { Ниво на апаратура полсигуряваща } \\
\text { фрункциониране на обекта и живот в него }\end{array}$ \\
\hline $\begin{array}{l}\text { КАиматична } \\
\text { (времева) }\end{array}$ & $\begin{array}{l}\text { За^есяване, разнообразна фрлора и фрауна, чист } \\
\text { вьздух, вьздушни течения, тишина, волни басейни, } \\
\text { стопанска и приемна част, камбанен звьн, к^епала }\end{array}$ \\
\hline Хигиенна & $\begin{array}{l}\text { Вентилация, полАрьжка, санитарен възел, вола } \\
\text { голна за пиене и обозначена, обезопасени водни } \\
\text { басейни и релефр, може ^и Аа се посещава с } \\
\text { храна и багаж }\end{array}$ \\
\hline
\end{tabular}




\begin{tabular}{|c|c|}
\hline $\begin{array}{c}\text { ВИА } \\
\triangle О С Т Ъ П Н О С Т\end{array}$ & КРИТЕРИИ ЗА ОЦЕНКА И ПОАСИГУРЯ્ЯАНЕ \\
\hline МеАицинска & $\begin{array}{l}\text { Аптечка, пункт за долекарска помощ, връзка с } \\
\text { болница и яснота на рисковете }\end{array}$ \\
\hline Ергономична & $\begin{array}{l}\text { Приспособен и издьржан архитектурен } \\
\text { екстериор и интериор, позволяваш оптимално и } \\
\text { безопасно Авижение; ясни противопожарни и } \\
\text { аварийни указания, Аобро ориентиране в } \\
\text { приролна среда }\end{array}$ \\
\hline Географска & $\begin{array}{l}\text { Картографриране, трасирани маршрути и } \\
\text { редовни пьтувания дотам }\end{array}$ \\
\hline Транспортна & $\begin{array}{l}\text { Наличие на Аостьп с различни видове и нива } \\
\text { ^ицензирани транспортни комуникации }\end{array}$ \\
\hline $\begin{array}{l}\text { Туристическа } \\
\text { (спортно- } \\
\text { рекреативна) }\end{array}$ & $\begin{array}{l}\text { Посетителски центьр, индоормационни и } \\
\text { указателни табели и книги, оптимално сьстояние } \\
\text { на санитарен възел за повече хора, качество на } \\
\text { настаняването и храната, възможност за } \\
\text { фотографиране; сувенири и визуална } \\
\text { илентичност, сьздалени в процеса на } \\
\text { брандиране на обекта и институцията }\end{array}$ \\
\hline Икономическа & $\begin{array}{l}\text { Елитен затворен обект или всеки може Аа си } \\
\text { позволи Аа го посещава редовно }\end{array}$ \\
\hline Археологическа & $\begin{array}{l}\text { Има ^и старини, руини, артефакти, проучват ^и } \\
\text { се (подльржани, осмислени, запазени, } \\
\text { експонирани, Аостьпни) настилка, себестойност } \\
\text { на посещението }\end{array}$ \\
\hline $\begin{array}{l}\text { Социална } \\
\text { (празник/Аелник) }\end{array}$ & $\begin{array}{l}\text { Възможности за разнообразна социализация на } \\
\text { обекта и посетителите; сбор, храмов празник, } \\
\text { богослужебен и културен календар и съответни } \\
\text { пространства достьпни и за гражлански } \\
\text { инициативи }\end{array}$ \\
\hline $\begin{array}{l}\text { ПеАагогическа и } \\
\text { андрагогическа, } \\
\text { поклонническа }\end{array}$ & $\begin{array}{l}\text { Наличие на детски кьт, място за отлих, хранене и } \\
\text { общуване, пространство за движение и спортове, } \\
\text { свобола за разглежлане и снимане, помощни } \\
\text { средства за хора сьс затруднения, кът за животни, } \\
\text { паркинг, настаняване, пьрва помощ, интернет }\end{array}$ \\
\hline
\end{tabular}

BARRIERS TO THE DIGITAL AND PHYSICAL ACCESSIBILITY OF THE 


\section{Аигитална и техническа}

Сайт и галерия с фотографии на управата и посетители, съзАалени от тях и преАставящи Аейности, мисия, визия; обогатяване с репортажи от разАичнИ събИтия, пО-често От НЯКОАКО ПьтИ ГОАИШНО;

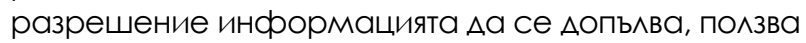
и разпространява; езикови, акустични, визуални и перорормативни (ритуални) подобрения на богослужението, видеостена, изкуства, Аекорация, хигиена; Аигитализиране с еАнакво внимание към ценни стари Аокументи и икони, богослужебни и покАоннически Аетайл, сезонна фрлора и фрауна; проследяване как растат Аецата и живеят м^аАежите, как работят и общуват възрастните; споделяне на гражАански успехи и признания, рекреативни и развлекателни Аейности и инициативи; уважаване на благотворителност, приАобИвки за мястото и хората; системно архивиране на инфформацията на стабилни носители в различни и реномирани локации и с Аобра техника; покани към волещи експерти и местни общественици и творци, колективи или прицьрковни кАубове, сьвместни изяви, участие вьв форуми, представяния, експозиции, кампании, феетивали, проучвания и публикуване на Аанните за местното живо и материално наслеАство

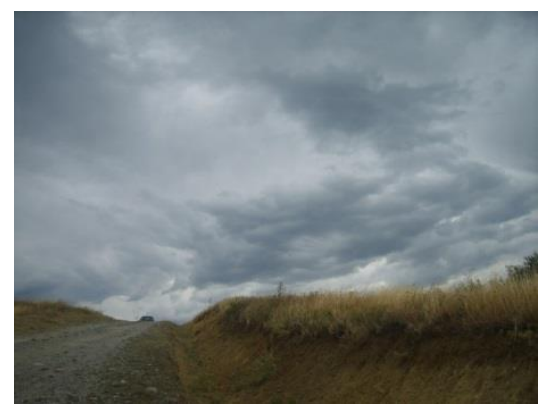

Фиг. 1. Пътят на връщане от сбора на Бистришки манастир "Свети богоотци Йоаким и Анна“"

Ао пьтя се стига с редовен градски транспорт, а прехольт от

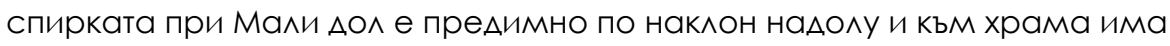
п^авен поАХОА, освен стрьмното параАно стьлбище при портата. 

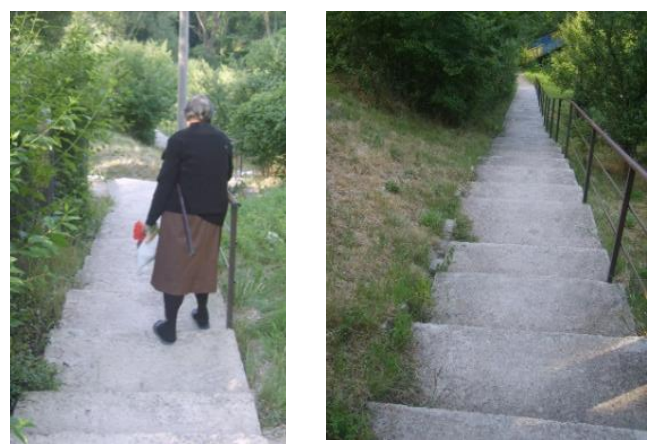

Фиг. 2. Стълбища на отиване на сбора на старата църква на кв. ВерАикал, Банкя, изградена на баир, в близост Ао спирка на реАовен граАски транспорт

Местните хора познават народния културен календар и с раАост посещават веАнъж в гоАината околните свети места в Аеня на техните храмови празници, когато е сигурно, че цьрквите ще са отворени.

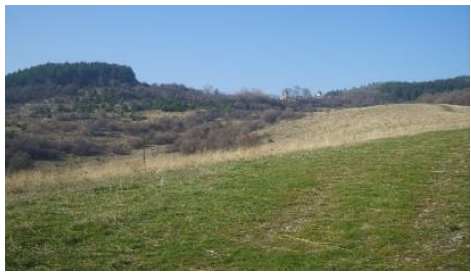

Фиг. 3. Изкачване към КАисурски манастир „Света Петка“ през село и пасище по обозначен маршрут от крайна спирка на редовен гралски транспорт и начало на ве^оалея

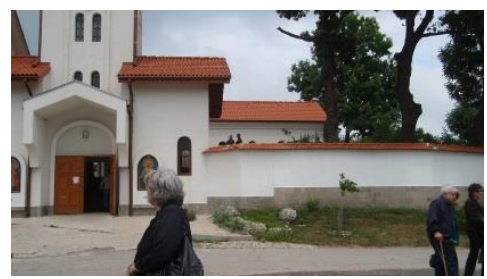

Фиг. 5. Плавен поАстъп към портите на пъстрия планински КАисурски манастир „Св. Петка“

СлеА ПОАСтьПа Се ИЗКачват НяКОАКО стьлбища, но в Авора има полегати

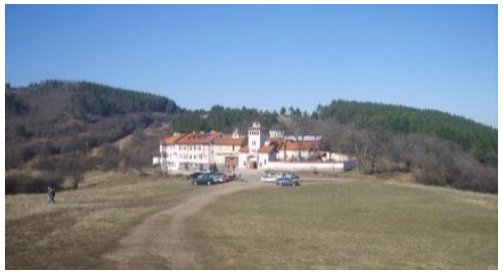

Фиг. 4. Изглеа към манастира в края на шосето и велоалея „Света Петка“
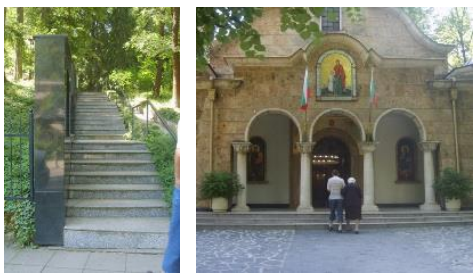

Фиг. 6. Стълбите и вХОАът КъМ красивия централен храм на Банкя 


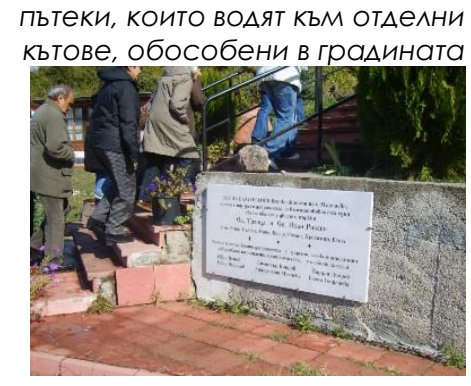

Фиг. 7. Стълбища посрещат навсякъАе непрестанния туристически поток

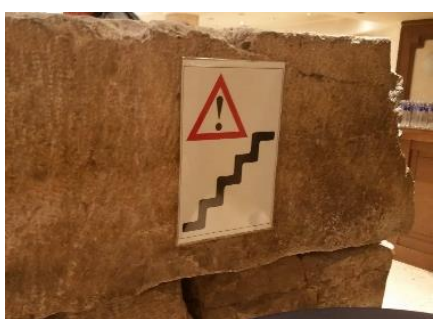

Фиг. 8. Обозначаване на социализираната в хотел част от останките от амфитеатъра на Сераика

Аарствените наАписи от фриг. 7 напомнят за необходимостта $А$ a се съзаават уАобства за върволицата поклонници обикалящи манастирите край столицата.

\section{^итература / References}

Bakalova, Elka, (2016). The Cult to Relics and Muraculous Icons: Traditions and Contemporaneity, Sofia, IEFEM-BAN, ISBN 978-954-322-836-2, 2016 (In Bulgarian) / (Бакалова, Елка, КУлтьт към реликвите и чУАОтворните икони: траАиции и Съвременност. С., ИЕФЕМ-БАН, ISBN 978-954-322-836-2, 2016)

Bogdanova, Galina; Sabev, Negoslav, (2017). Accessibility of Tourist Services for People with Disabilities (in Bulgarian), Science series Cultural and Historical Heritage: Preservation, Presentation, Digitalization (P. Petkov \& G. Bogdanova, Eds.), volume 3, issue 1, ISSN 2367-8038, pp. 156-163, [http://www.math.bas.bg/vt//kin/files/papers/3 1/12-KIN-3-12017.pdf, (Last view: 24.08.2019)]

Douleva, Stela, (2019). Small Chappels and Prayer Places, Electronic Magazine LiterNet, 1999-2019, ISSN 1312-2282, 06.03.2005, No3 (64) (In Bulgarian) [https://liternet.bo/publish14/s duleva/malki.htm, (Last view: 24.08.2019)] / [Cтелa Аулева, Малки параклиси и проскинитарии, Електронно списание LiterNet, 1999-2019, ISSN 1312-2282, 06.03.2005, №3(64)]

Georgieva-Angelova, Albena, (ed.) (2013). Holy Places in the Region of Sofia: Cults, Narratives, Images, Sofia, IEFEM-BAN, ISBN 978-954-322-669-6, 2013 (In Bulgarian) / [Георгиева-Ангелова, Аибена, (сьстав.), Свети места в софийско. Култове, разкази, образи. София, ИЕФЕМ-БАН, ISBN 978-954-322-669-6, 2013] 
Piperkov, Paskal, (2014). Pilgrimage Routes at Holly Mount of Tarnovo (in Bulgarian: Поклоннически маршрути в Търновската Света гора), Science series Cultural and Historical Heritage: Preservation, Presentation, Digitalization (P. Petkov \& G. Bogdanova, Eds.), volume 1, issue 1, ISSN 2367-8038, pp. 60-80, [http://www.math.bas.bg/vt/kin/files/papers/1_1/07-KIN-1-1-2014.pdf, (Last view: 24.08.2019)]

Sabev, Negoslav; Bogdanova, Galina, (2018). Digital and Physical Accessibility of Tourist Places in Bulgaria (in Bulgarian), Science series Cultural and Historical Heritage: Preservation, Presentation, Digitalization (P. Petkov \& G. Bogdanova, Eds.), volume 4, issue 2, ISSN: 2367-8038, pp. 38-58, [http://www.math.bas.bg/vt/Kin/files/papers/4 2/04-KIN-4-2-2018.pdf, (Last view: 24.08.2019)]

Shabarkova-Petrova, Mariyana; Galabova, Liana, (2018). Pilgrimage of Believers with Special Needs at the Heart of Holly Mountain of Sofia City - Study and Paradoxes of a Mission Almost Imposible Today (in Bulgarian), Science series Cultural and Historical Heritage: Preservation, Presentation, Digitalization (P. Petkov \& G. Bogdanova, Eds.), volume 4, issue 2, ISSN 2367-8038, pp. 229-269, [http://www.math.bas.bg/vt/kin/files/papers/4 2/15-KIN-4-2-2018.pdf, (Last view: 24.08.2019)]

Sharlanova, Valentina, (2013). Holy Mounth of Sofia. Monasteries around Sofia, Sofia, BAN, ISBN 978-954-322-567-5, 2013 (In Bulgarian) / [Шарланова, Валентина, Софиийската света гора. Манастирите около Софрия, С., БАН, ISBN 978-954-322-567-5, 2013]

Valchinova, Galina, (2006). Bulgarian Visionaries and Fortune Tellers rom 20th Ceentury, Sofia, Balgarski Bestseller, ISBN 954-463-014-7, 2006 (In Bulgarian) / [Въ^чинова, Га^ина, Балкански ясновиАки и пророчици от XX век, С., Български бестсельр, ISBN $954-$ 463-014-7, 2006] 


\section{КУАТУРНО-ИСТОРИЧЕСКО НАСАЕАСТВО: \\ ОПАЗВАНЕ, ПРЕАСТАВЯНЕ, АИГИТААИЗАЦИЯ}

CULTURAL AND

HISTORICAL

HERITAGE

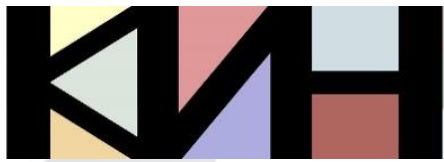

PRESERVATION PRESENTATION

DIGITIZATION
Материалите в сборника са обект на авторско право. Разрешава се безвъзмезАното ползване на техни електронни/ хартиени копия само за лична употреба или обучение, при пь^но цитиране на текущата страница и слеА писмена декларация от цитиращия за Аипса на търговски намерения. За копиране пол Аруга фрорма, препубликуване или публикуване на сървъри се изисква писмено разрешение и/или заплащане.

() Авторски колектив, 2019 Технически реАактори: Николай Ноев Калина Сотирова-Вълкова Ка^оян Николов

\section{Editors}

Galina Bogdanova

Vanya Mateeva

This work is subject to copyright. Open and free of charge use of digital/hard copies of publications is granted only for personal or educational use, with full citation of the current page, and after written declaration of the quoting side for not-commercial Intention. For any other reproducing types, republishing, photocopying, recording, or any other storage retrieval system/ server written permission and/or fee is required.

(C) Authors` Group, 2019

Technical editors:

Nikolay Noev

Kalina Sotirova-Valkova

Kaloyan Nikolov

Научна поредица: том 5, брой 2 (7)/2019

Science series: vol. 5 , issue $2(7) / 2019$

www.math.bas.bg/vt/kin

ISSN: 2367-8038 